\title{
A Realist Interpretation of Chika Unigwe's On Black Sisters' Street
}

\author{
Laura Haruna-Banke \\ Department of Educational Foundation and General Studies, J. S. Tarka University, Makurdi-Nigeria
}

Iorwuese Gogo (Corresponding author)

Department of English, Benue State University, Makurdi-Nigeria

Email: gogoiorwuese8@gmail.com

Received: 02/08/2021

Accepted: 05/11/2021

Published: 01/01/2022

Volume: 3 Issue: 1

How to cite this paper: Haruna-Banke, L., \& Gogo, I. (2022). A Realist Interpretation of Chika Unigwe's On Black Sisters' Street. Journal of Critical Studies in Language and Literature, 3(1), 32-40

DOI: https://doi.org/10.46809/jcsll.v3i1.124

DOR: https://dorl.net/dor/20.1001.1.27324605.2022.3.1.4.1

This work is licensed under the Creative Commons Attribution International License (CC BY 4.0). http://creativecommons.org/licenses/by/4.0/

\section{(c) (i)}

\begin{abstract}
This paper is a realist interpretation of Chika Unigwe's On Black Sisters' Street. The text is considered for study here because it dwells on the popular, the modern and social issues that define realist works. The paper involves realism of subject-matter and social realism as its theoretical tools for the evaluation of the research subject. Realism of subject-matter deals with themes that are common to society while social realism looks at the poor social conditions of the middle and lower classes. The paper is a qualitative research and it is based on a content analysis of the select text for study. The paper probes the ugly life of four young girls in Nigeria who are trafficked into Antwerp, Belgium, to work as prostitutes and earn income for their traffickers. The girls suffer from sexual abuse and deceit from their parents and older men. They undergo hardship as a result of lack of proper parental care, unemployment, insecurity and poor social services which make them frustrated. All of these make their lives vulnerable. Therefore, the study concludes that, well placed individuals, parents, civil society organizations and the government should make efforts to improve and secure the lives of vulnerable young women in Nigeria in order to help them escape from their vulnerabilities. Also, the novel's authentic representation of life and society and its focus on character more than plot, including its attention to the lower class, the social and the contemporary issues fits it into the realist agenda.
\end{abstract}

Keywords: Realism, Realism of Subject-Matter, Social Realism, Novel, Prose-Fiction

\section{Introduction}

Although the great influence of the realist movement in literature was waned with the emergence of the 20th century modernism and postmodernism, which focuses on disillusionment and fragmentation caused by the horrible impacts of the 20th century world wars, realism is still a core aspect of literature, especially prose fiction, considering verisimilitude. The realist movement in literature emerged in the 19th century with the aim to representing original human stories against Romanticism which was based on the idealisation of life and society. Realism was massively accommodated by the masses 
for the fact that it favoured the working class and represented their stories truthfully against the special and adventurous stories of nobles, kings, queens and great men of valour which favoured the bourgeoisie. Realism flourished alongside the industrial revolution in the 19th century in Europe which marked the emergence of the working class and their great desire for reading stories that represented their real life circumstances. This was when the novel, which initially emerged in the late 18th century, grew and became popular with the people because it was focused on representing stories of the ordinary people with common characters and themes. And for the fact that realism was massively growing in influence both in literature and philosophy, most novelists of that period imbibed the principles of realism in the production of their novels. The novel then grew propagating the ideals of realism which are the authentic portrayal of human stories, the use of ordinary characters and the focus on common issues. The novel is realistic prose fiction in such a way that it can demonstrate its relation to real life (Hasan, 2015). Therefore in Europe, Daniel Defoe's Robinson Crusoe (1719) and Henry Fielding's Tom Jones (1749) are some of the early English novels. The novel then flourished with the massive contributions of authors like Charles Dickens, Thomas Hardy, Mark Twain and John Griffith among several others whose works portray individual stories of ordinary people and their social conditions in reality.

In Africa, the novel also exists and chiefly reflects the cultures of the various ethnic groups, the social reality of the people and their colonial experiences including post-colonial challenges. In fact, it relates the African story to the world. However, the African novel emerged from the contact of Africa and Europe through Trans-Atlantic trade, colonialism and the introduction of Western education. In this case, Irele (2010) states that Africa has had a long and enduring tradition of poetry and drama, the novel is today, as almost everywhere else in the world, the dominant literary genre on the continent. Its privileged status as a written genre may be attributed to European influence and its association with an imaginative consciousness grounded in literate modernity. According to Gikwandi (2007, p. 54), "what is now considered to be the heart of literary scholarship on the continent could not have acquired its current identity or function if the traumatic encounter between Africa and Europe had not taken place". This shows that the contact between Africa and Europe majorly through colonialism inspired the rise of African authors who represent the African story in detail and without bias. The pioneering African authors of the novel that have influenced its massive development include; Sol Plaatje, Chinua Achebe, Casely Hayford, Peter Abrahams, Ngugi wa Thiong'o, Nadine Gordimer, Flora Nwapa, Ayi kwei Armah, Camara Laye and Ferdinand Oyono among others.

The novel also flourished in Nigeria beginning in the colonial era. This was where authors like Amos Tutuola, D O. Fagunwa and Cyprian Ekwensi made various attempts to portray their socio-cultural milieu. This was followed by Chinua Achebe's landmark publication of 1958, Things Fall Apart, that gave credence to not just Nigerian literature but modern African literature overall. A host of authors such as Flora Nwapa, Buchi Emecheta, Abubakar Gimba, Chukwuemeka Ike, Festus Iyayi, Isidore Okpewho, Zainab Alkali, Femi Ademiluyi, Ifeoma Okoye, Ben Okri, Helon Habila, May Ifeoma Nwoye, Chimamanda Ngozi Adichie, Sefi Atta, Chika Unigwe, Samuel Anula and several others followed suit with numerous publication of novels that reveal the pre-colonial, colonial and post-colonial social, political and environmental realities. Such themes common to their works include; the traumatic experiences of colonialism, post-colonial political instability, the Nigerian civil war, military dictatorship, ethnic bigotry, poverty, corruption, bad leadership, insecurity, emerging social trends in urban areas, subjugation of women, girl-child abuse, emigration, environmental degradation and diasporic experiences among others. These, therefore, contribute to the exploration and exposition of life in Nigeria as lived albeit with the embellishment of the imaginary - through the novel.

The aim of this paper is to examine the realist features in Unigwe's On Black Sisters' Street (2010). Its objective is to reveal the realist features in the select novel. The paper starts with introduction which gives an insight to the topic of discussion followed by review of literature, statement of the theoretical framework, analysis of the select novel and conclusion.

\section{Review of Literature}

This part of the paper has presented critical views and reviews on Unigwe's On Black Sisters' Street (2010) in order to identify a gap for this present study to fill. On Black Sisters' Street has received a variety of criticisms. Thus, Umezurike's (2013) critique "Sexuality and Subjectivity in Chika Unigwe's On Black Sisters' Street" deems the novel to be a chart of the lives of four girls who, hoping to escape the heartbreak, abuse and poverty in Nigeria, end up as prostitutes in Antwerp, Belgium. He discusses it from the perspectives of "Understanding Sisi: Subject through dreams and prophecy", "Understanding Efe: Subjection through fancies and desires", and "Understanding Alek: Subjection through familial norms". These analyses reveal the sexual objectification of the female characters in the novel and the driving forces that lead them into prostitution. In their study, "Ideational Representation of Prostitution in Chika Unigwe's On Black Sisters' Street", Kamalu and Ejezie (2014, p. 258) concludes that,

[...] a linguistic study of Ideational meanings in the text under consideration enables the analyst to deduce how the writer's choices serve as a means through which social meanings and experiences can be expressed and understood. The significance of this study lies in its demonstration of how the writer's linguistic choices bring about an understanding of the social experiences and ideology that underlie the text under study thus, the ideology encoded in the text helps us to discover and understand issues of character depiction, identity, sexual violence and gender roles and asymmetry in Nigeria and Belgium. 
This clearly shows that Kamalu and Ejezie's study concerns itself with unveiling the linguistic composition of the novel and how it has been able to expose the encounters of the characters and the ideological leanings of the novel.

Orabueze (2013) examines "The Law and Slave Trade: An Evaluation of Sex-slavery in Chika Unigwe's On Black Sisters' Street". She reveals that laws have been in place to curb sexual abuse of minors and human trafficking that result to women ending up as sex-slaves. But these laws do not actually protect vulnerable women and girls and they fall prey to men and trafficking cartels who ravished their bodies and dreams. This, she writes, happens both domestically and internationally. On the domestic front, men rape their daughters, domestic staff; engage in polygamy and wife inheriting for the sake of sexual pleasure and nothing else. On the international level, young girls are trafficked and made to work as prostitutes while their traffickers earn the profit of their business of the flesh. This is captured in the article thus:

On Black Sisters' Street presents two forms of sex-slavery - domestic and transnational.... Both domestic and transnational sex-slaves are regarded as inferior beings by their traffickers. There is no difference between the treatment madam gives to the trafficked in Antwerp and Ama's mother's friend's treatment of her housemaid. In Europe, the sex slaves are stripped of their identities. Sisi's real name is Chioma but before she leaves Lagos for Antwerp, she decides on her own to use the name of Sis, and that's what she even tells her boss, Madan. Before her death, the other three women - Efe, Joyce and Ama do not know her real name or anything about her. (P.62-63)

It is deduced from the foregoing that the inhuman treatment meted at young girls held under the bondage of sex-slavery by traffickers and tricky employers degrades their dignity and identity as humans.

Eze's (2014) "Feminism with a Big "F": Ethics and the Rebirth of African Feminism in Chika Unigwe's On Black Sisters' Street" places Unigwe in the third generation of Nigerian writers alongside Chimamamda Ngozi Adichie, Unoma Azuah and Lola Shoneyin among others. To Eze, Unigwe though recognising the efforts of her ancestors in writing - Flora Nwapa, Zulu Sofola, Buchi Emecheta among others - who have fought the women cause in their writings (but which they have recognised as feminism with a small "f", a saying alluded to Emecheta), Unigwe and her generation has taken the fight to a high level adopting Western feminist ideals which are radical. This then makes their feminist stance to be regarded as feminism with a big "F". This means that their form of feminism is a shift away from the "softer" form of the first generation of women writers and it is radical feminism. This is what is found in her novel, On Black Sisters' Street.

Ibeku's (2013) article "Sexuality and Diasporic Experiences in Chika Unigwe's On Black Sisters'Street" reveals that,

On Black Sisters' Street concentrates on the issue of African women who migrate to Europe with the sole aim of making a living with their God-given endowments. They left in order to help themselves achieve what their government has failed to provide for them. They are aware and accept to earn a living through prostitution as a result of the corrupt practices in the countries. (p.3)

Ibeku's view here reveals the push and pull factors of young women migrating to Europe. The push factors include; poverty, unemployment, insecurity, political instability and poor social welfare while the pull factors are stable life, better source of income and security. However, in Europe, the migrated girls indulge in prostitution as a means of earning a living which they were aware of before migrating.

These foregoing critical articles on Unigwe's On Black Sisters' Street have helped in developing knowledge documents on the novel therefore adding intellectual value to it and helping scholars and critics to have a better understanding of it and prose fiction in general. However, the critical articles have not explored all aspects of the texts. For instance, they dwell mostly on feminism, postcolonialism, diasporic experiences, sex-slavery and human trafficking. Therefore, there is a gap in the aspect of realism which has not been much explored, so this study will evaluate the select novel from the realist perspective.

\section{Theoretical Framework}

This paper adopts realism, in particular realism of subject-matter and social realism, as its theoretical framework in the study of the research subject. Realism is a term that gained currency on the continent of Europe about the middle of the nineteenth century, to denote a new mutation in the development of prose fiction which had manifested itself a couple of decades earlier around 1830 (Coyle et al, 1987). Realism as one of the earliest literary theories and movements has stimulated massive literary creations and criticisms. It focuses on subjects that are common, social and contemporary in nature. And recognising that character is produced by both intrinsic and extrinsic imperatives, sensing that these imperatives are brought inevitably into stark relief in a world moving toward technologisation, realism addresses itself in a degree of pragmatic efficiency to the problems at hand (Kearns, 1996). Realism is a movement in art and literature that began as a shift against the exotic and poetic conventions of Romanticism. Literary realism allowed for a new form of writing in which authors represented reality by portraying everyday experiences of relatable and complex characters, as they are in real life. Literary realism depicts works with relatable and familiar characters, settings and plots centered on society's middle and lower classes (literarydevices.net 2021).

In discussing realism in his work titled Literary Criticism from Plato to the Present: An Introduction, Habib (2011) presents that,

A tendency towards realism arose in many parts of Europe and in America, beginning in the 1840s. The major figures include Flaubert and Balzac in France, Dostoevsky and Tolstoy in Russia, George Eliot and Charles Dickens in England, as well as William Dean Howells and Henry James in America. The most general aim of 
realism was to offer a truthful, accurate, and objective representation of the real world, both the external world and the human self.... Realism was thus a broad reaction against idealization, historical retrospection, and imaginary worlds of Romanticism. (p.169)

Habib's view point unveils the historical roots of realism in literature and its acclaimed fathers. It affirms that realism emerged as a reaction against Romanticism, a literary school of thought aimed towards making everything seem beautiful. Also the view point relays the foundation of realism which is objectivity, observation and factuality. Rohmann (1999) defines realism as the attempt to present the world as it appears to the everyday senses. This proves that realism deals with the ordinary in society. Fundamentally in literature, realism is the portrayal of life with fidelity. It is thus not concerned with idealisation, with rendering things as beautiful when they are not, or any way presenting them in any guise as they are not; nor, as a rule, is realism concerned with presenting the supranormal or transcendental (Dictionary, 1998). The realist novelists paid particular attention to exact documentation, to getting the facts right, and in many ways were continuing in a more intensive and conscientious fashion what Balzac had been doing years before in La Comédie Humaine (Dictionary, 1998).

Realism is an exceptionally elastic critical term, often ambivalent and equivocal, which has acquired many qualifying adjectives (Dictionary, 1998). By this, there are several branches of realism known as social realism, socialist realism, surrealism, magical realism, psychological realism, realism of subject-matter, symbolic realism, conscientious realism, irrealism, neo-realism, realism of philosophy, critical realism and realism of technique. Out of all these branches of realism, this paper selects realism of subject-matter and social realism for analysis of the select text because they are relevant in the concerns of the text.

Realism of subject-matter according to Becker (1980) refers to what can be considered as literarily realistic. That is the subject areas that can be considered as real. What is real must be "immediately visible, here and now". Becker (1980, p. 45) further states that "if realism has done nothing else it has shifted the focus from traditional bookish and oft repeated materials to the strictly contemporary...the first impulse of the writer of our day is to treat the life around him..." He argues that the theme of the work of a realist writer must revolve around the "popular, social and modern" which produce realism albeit they are not only related to it (Becker 1980, p.46). Snircova (2015) in his book, Realism, Modernism, Postmodernism: Five Modern Literary Texts in Context, explains that realism of subject-matter is based on the three main beliefs that the world exists in exactly the same form for everyone. This suggests that individual perception is redundant and that simple observation is the main source of our knowledge of the world. The second is the assumption that human language directly represents images of objects and things, and the third is the belief that it is possible to draw a clear line between subjective ( or personal) and entirely objective perceptions of reality.

Social realism on the other hand is interested in exploring problems of social, economic and political inequality and the experience of urban life. The early forms of social realism in literature appeared in the works of Charles Dickens, with his depictions of work houses, the homeless and down trodden workers. Nikolai Gogol and Fyodor Dostoyevsky chronicle the lives of lower government functionaries and Victor Hugo wrote elegiacally about the lower class' struggling for survival and humanity. Social realism in literature holds a glaring spotlight on the lives of these characters as a means of criticising the social structures that keep them in 'their' place (Hurwitz, study.com 2021).

\section{A Realist Interpretation of On Black Sisters' Street}

The novel, On Black Sisters Street (2010), unveils the predicaments of young girls that have been trafficked into Antwerp, Belgium to work as sex workers and earn money for their boss. Thus the background of each of them provides readers with the socio-economic and political reality in Nigeria and to some extent Africa in general. The young girls are four in number bearing such names as Sisi, Ama, Efe and Joyce, all of whom have been trafficked from Lagos, Nigeria, to Europe, Antwerp, Belgium, by Senghor Dele.

The first of the girls to have her identity and background revealed is Sisi whom the story revolves around. Sisi's real name is Chisom, however, she changes her name to Sisi on her way to Europe in order to bear a different identity and live a fresh life which is common to most prostitutes who travel out of their locality for prostitution. Sisi is a daughter of a Lagos based civil servant and a graduate of business administration in the University of Lagos. After graduating from the university, she finds it difficult to have a job and support herself and her family who expect her to assist her younger siblings acquire education too. She has submitted so many job applications but is not invited for any job interview. However, her parents' income is so low that it is difficult to get a better accommodation for the family let alone meeting the family's general needs. This makes Sisi frustrated with life and living in Lagos. This is captured thus:

...two years after leaving university, Chisom was still mainly unemployed and had spent the better part of the two years scripting meticulous application letters and mailing them along with her resume to the many different banks in Lagos.... But she was never invited to an interview. Diamond Bank. First Bank. Standard Bank. And then the smaller ones. And then the ones that many people seemed never to have heard of. Lokpanta National Bank. Is this a bank? Here in Lagos? Is it a new one? Where? Since when? Even in their obscurity they had no place for her. No envelopes came addressed to her, offering her a job in a bank considerably humbler than the banks she had eyed while at school, and in which less intelligent classmates with better connections worked. (p.20-22) 
This is Sisi's condition and it also reflects the social reality in the Nigerian society where thousands of university and tertiary institutions' graduates have filled the labour market which is unfruitful. The government does not provide enough jobs or employment opportunities for graduates. The private sector too is too thin to accommodate a lot of graduates. Most sectors of the private sector pay very meagre wages that do not help in the harsh economic situation in the country. Therefore unemployment is the order of the day with its attendant consequences of poverty, crime, frustration and desperation. Most of the people caught in this are the youths who have the highest population in the country. And in most situations, their journey in education is conditional which means that their parents strive to send them to school to enable them get employed after graduation and assist them and their younger ones. Once one fails to get a job years after graduation, one is considered a failure and one becomes frustrated with life and seeks desperate means of survival which is a trend that is putting the youths into trouble. This is where some seek to travel abroad to seek for greener pastures and most times ending up being trafficked for cruel and illegal business.

As Sisi's unemployment status prolonged and the weight of her parents'and siblings' expectations from her deepen and her desire to escape poverty and turn her fortunes around overwhelms and haunts her, she becomes open to whatever opportunity that comes her way to improve her life. Then she meets a human trafficker, Dele, who sends beautiful girls to Antwerp, Belgium, in the guise of helping them have jobs and escape the poverty in Nigeria. But in reality they go there and work as prostitutes to earn money for him. He disguises himself as a business man, importer/exporter, and lures young girls to Europe. Sisi is making her hair in a saloon while Dele brings a young girl for her hair to be made shouting on top of his voice that she is going to Europe. Sisi gets curious and asks the girl what she is going there to do. Dele then jumps in and asks Sisi if she wants to go to Europe too. He hands Sisi his business card to contact him so that they will discuss and make proper arrangements. Sisi is suspicious of Dele's intents but her poor condition and a broken relationship with her parents makes her visit Dele's office to see how he can help. This comes out thus:

When she got home that night and she had to eat gari and soup for the third day in a row she thought nothing of the man's offer. The next day, when he came home to announce that there were rumours of job cuts in the civil service - 'They are likely to let me go. Twenty-four years and pfa, to go because I am not from Lagos State!' Chisom merely brought out the card and fingered it. As she would something beautiful, some silk underwear perhaps, and put it back in her purse. When she went to the toilet and found the cistern broken and pan overrun with squirmy maggots and a day's load of waste - there was a city-wide water shortage - she felt short of breath. She needed to get out of the house. Go for a walk. And even then she had no destination in mind until she found herself at an office on Randle Avenue, standing at the address on the gold-edged card, that she had, somehow without meaning to, memorised. (p.33)

This is the rate at which Sisi and her family's socio-economic condition deteriorates. It moves from bad to worst and her frustration increases. She then had to make the hard decision of meeting Dele in his office to see how he can help even though she is suspicious of his life style. Also it unravels the reality of the level of squalor that ordinary Nigerians live in albeit some being civil servants. This is for the fact that social amenities and salaries of workers are not well catered for. Sisi's father has worked in the civil service for twenty four years without promotion and salary increase. He has to manage his little income to cater for his large family which is not easy. He lives in two bedroom apartment with five grown children, a small kitchen and a small bathroom toilet which he shares with his family and other tenants. Water supply becomes short and water scarcity looms. To bath, flush the toilet and cook is difficult. Amidst this, the infrastructure in the apartment degrades and living in it is unbearable. Therefore Sisi would appreciate anything that she can do to escape this horrible situation.

Sisi meets Dele in his office and he tells her of how he can help her get out of her sorry situation. And his deal is to send her to Europe, especially Antwerp in Belgium. He brags before her that he has friends overseas that can help and that he sends girls abroad yearly. What the girls do there to survive is a secret though it is partially hinted for the fact that Dele only deals with beautiful girls and appreciates their physical qualities erotically which he often says will have them something reasonable to do. This is the offer Sisi is given by Dele. Its terms are difficult. She is to pay him thirty thousand Euros upfront or get to Europe and be paying instalmentally, five hundred Euros per month. This is captured thus:

In his office Dele's voice was not as loud as it had been in the salon the other day. Perhaps, Chisom thought, the rug and the air conditioner swallowed up the noise. Or perhaps it was the sheer distance put between them by the massive wooden table he sat behind, his stomach tucked neatly away from sight, that softened his voice. 'I dey get girls everywhere. Italy. Spain. I fit get you inside Belgium. Antwerp. I get plenty connections there. Plenty, plenty!' He panted with effort of talking. Hmph, hmph.... 'But I no dey do charity o. So it go cost you. Taty t'ousand euro it go cost you o'. ... when you get there, begin work, you go begin dey pay. Instalmental payment we dey call am! Mont' by mont' you go dey pay me'. (p.33-35)

Chisom thought maybe she should go. Just walk out the door because the man was obviously a joke. Every month she would send five hundred Euros. 'Or any amount you get, minimum of a hundred, without fail'. The without fail came out hard. A piece of heavy wood, it rolled across the table and fell with a thud. Any failure would result in unpleasantness, he warned. 'No try cross me o. Nobody dey cross Senghor Dele!'... (p.42)

Sis's interaction with Dele reveals the reality of how young girls in Nigeria are lured by traffickers for a ticket into Europe with promises of a better life which is not clearly spelt out. And in the process they massively exploit the willing travelers to their full advantage. Dele promises to help Sisi go to Europe but with a condition that she will pay him a huge sum of thirty 
thousand Euros. On Sisi's protest he tells her that it is when she gets there and starts work that she will be paying instalmentally, five hundred Euros a month which is still huge if there is nothing really reasonable to hold onto. But Dele has his plans and knows what he wants. It is just to make them work as prostitutes for the fact that sex sales very well in Europe. Especially that African girls provide a cheap option and experimentation for white men. Therefore the girls pay Dele his thirty thousand Euros bit by bit. This enriches Dele and his ring of traffickers so much at the peril of the victims. Meanwhile it takes them so many years to pay that by the time they finish, they get older and lost their physical value to attract sex customers. Thus they connive and recruit more young girls and make them work under them so that they will make their own profit. So the ring of trafficking continues and expands and more girls are fooled into it and exploited. This is a social ill and a reality in Nigeria that has caused adverse social disorder. Also, Dele's physique, arrogant speech and use of Pidgin English reveal that he is a thug common to Nigeria. This is realised through photographic and authentic description of Dele's personality and physical attributes which is the realist technique of portraying characters in prose fiction.

Sisi finally arrives in Antwerp, Belgium, via Dele's arrangements. She is picked by Segun, one of Dele's associates in Belgium, and taken to Zwartezusterstraat where Dele's trafficked girls are kept under a Madam who inducts and coordinate their activities in the sex industry. Sisi's first encounter with the Madam is presented thus:

....'I am your Madam', she said by way of introduction, walking over to the window and opening Sisi's blinds.

'heard you arrive safely. I trust you have rested well. Today you start work. We haven't got any time to lose'....

'Dele was right about you. Ah, that man knows his stuff. He never disappoints. He has the best girls on show, you know? To see the girls some of these jokers bring in! Ugly faces, bodies that need serious panel-beating and breasts hanging like scrotums'. She laughed.... 'Ah, hand over your passport. From now until your debt is paid I am in charge of it.' (p.117-119)

From this extract, the reality of Sisi's job and existence in Europe dawns on her. She fully realises the nature of her work, prostitution. Her passport is seized meaning that she cannot travel anywhere outside of Belgium again thus she is living at the mercy of her traffickers. As Sisi's experience here shows, it goes to prove the reality of girls who are trafficked as sex slaves to Europe. They live under threats and stringent conditions. They have no freedom, cannot earn their income but make huge amount of money for their traffickers.

After Madam had introduced herself to Sisi, she gives her materials and tips on how to operate in their business. This seen where the narrative voice reveals that:

...She pulled on the skirt Madam had chosen. Clenched her teeth and reached behind to pull up the zip. Triiiiiiip. She looked at the blouse. Laughed. Pulled it over her breasts with aggression. She pursed her lips and smeared on lipstick.... She was a dream-maker in silver and gold. These were not clothes she would ever have picked out for herself. Not even for this job: a blouse that hugged her intimately, sequined in silver. A goldcoloured nylon skirt which showed her butt cheeks when she bent. (p.201-202)

The tight clothes that Sisi wear reveal her erogenous zone which fits her in the sex business and prepares her for the task of the trade. Madam then takes Sisi to a bar where she will be hanging around to wait for men, customers, and seduce them to buy more drinks while offering sexual services to interested ones for pay:

Madam tapped Sisi on her shoulder. Lightly but with urgency and authority. The man behind the bar had extricated himself and to Sisi's surprise was not as portly as he had looked behind the counter.... He smiled at the two women, his teeth gleaming at them. He nodded, raked his fingers through straight, black hair, brought out his hand and traced Sisi's figure. 'Very good, Madam, Very good. She knows the drill? Ja? Here, the klanten...how you say "klanten"?' He turned to Madam and she provided the lost word. 'Customers."Yes, "customers". Thank you. The customers, they come first, ja? Make them drink. Make them buy lots of drinks. Much, much drinks. Expensive drinks. You give me business, I give you business, no? (p.207)

It is clear here that the role of Sisi is to make money for the bar owner and for her trafficker, Dele. The way that Sisi is forced to dress seductively, the location she is to hang in, the role that she is to play and the manner in which the bar owner traces her figure indicates sensuality and prostitution. This proves the inhuman treatment meted at trafficked girls as their free will and dignity is trampled upon. Sisi's experience in the hands of the Madam and the bar owner indicates reality because it is obtainable in society.

Sisi begins to wait around the bar to have men have sex with her and pay her. She is not contented with the job and the bar environment. Though reluctantly, she does what she has to do and pays Dele his demand of five hundred Euros monthly. A place is later found for her at a show room where she stands in a glass and strike seductive poses to attract her customers. However, she keeps losing interest in the business as it is demeaning to her perceived personality, a university graduate of business administration. Her interest continues to wane until she meets a boyfriend, Luc, in a church that she attends. The boyfriend loves and adores her despite being aware of her status. She decides to quit the prostitution, get married to Luc and looks for something credible to do. She skips her monthly remittances of five hundred Euros to Dele and then Dele and his Co gets her killed. This is divulged thus:

When Sisi answered and found Segun at the door she was surprised but not alarmed. 'Hello, do you want to come in? He did not want. 'Bu...bu...but I want you to come, I mean ... to ... to ... to come with me in the car. We ... we ... we ... I mean, we ... we ... we have some... thing to dis...dis...to discuss'. Busy hands flailing all the while. Restless feet tapping on concrete. ... 'No. I am sorry, Si...si. Not here. No... no ... I mean, not here. It ... it... it wo ... wo ... won't take time, I promise'. His voice was low. He clenched and unclenched his fists. It struck 
Sisi that this was the longest he had ever spoken to her.... She was not scared of Segun. He was harmless, everyone knew it. So the hammer hitting into her skull had come as a shock. She did not even have time to shout. She was not yet dead when he dragged her out on the deserted road leading to the GB and pushed her into the boot of the car, heaping her on top of a purple-and-grey plaid blanket.... (p.292-293)

Sisi's murder confirms the dreaded reality of human trafficking and the wickedness of its perpetrators.

Efe is one of Sisi's house mates in Zwartezusterstraat, Antwerp, and has a story that reveals the social reality in contemporary Lagos and Nigeria in general. She loses her mother at an early age and being the eldest child, the responsibility of handling the home and taking care of the younger ones is rest with her. Meanwhile, her father has lost control of himself after losing his wife. He turns to drinking alcohol and has no time for his children. He works as a labourer, earns little and gives little to Efe for family upkeep. No other basic necessities are provided by him. Efe grows into adolescence and out of naivety is lure by a forty-five year-old man, Titus, who is married, into being his sex partner. Titus compliments her with money which she uses in buying clothes and other necessities for herself and her siblings. Titus engages in marathon sexual intercourse with Efe almost on daily basis. He eventually impregnates her and when she reveals it to him, he dumps her and disappears. This comes out in the text thus:

Efe discovered sex at sixteen at the back of her father's flat. That first experience was so painful, so ordinary that she had spent days wanting to cry. She had had no notion of what to expect, yet she had no thought it would be this lucklustre, this painful nothing. She felt somewhat cheated, like pikin wey dem give coin wey no dey shine at all at all. She remembered nothing but a wish that it would not last too long and that the pain between her legs would be well compensated. The man who held her buttocks tight and swayed and moaned and was responsible for all that pain was forty-five. He was old. Experienced. But most importantly, he had a fortune that was rumoured to be vast. Money wey full everywhere like san' san'. He had promised Efe new clothes. New shoes. Heaven. Earth. And everything else she fancied between the two as long as she let him have his way. (p.49)

...Every afternoon, for the next four months, Efe saw Titus at his insistence. He said she had taken possession of him, he had never wanted a woman as much as he wanted her. (p.56)

The detail manner in which the first sexual experience of Efe and her sexual exploitation by the old and experienced Titus and how Titus is described as using pidgin English to flatter Efe shows reality which is identifiable in the setting of the text, Lagos, Nigeria. What is revealed in the excerpt exposes the reality of how rich old men in Nigeria lure young innocent and vulnerable girls into a sexual relationship with money and so many lies. They leave their wives at home and go on sexual tourism with such young girls for their personal pleasure. For them it is all about the pleasure and they always have it. However, the young girls end up being ruined where either they get pregnant and get dumped or made to do abortion which is life threatening or they get infected with dreaded sexually transmitted diseases. Sometimes these young girls naively have children for these old men who on the other hand turn them down making them frustrated and desperate with life.

Titus impregnates Efe and runs away. Efe feels betrayed and suffers with the pregnancy alone. She rejects abortion for pains involved in it and decides to keep the baby. She gives birth to a son but Titus does not turn up to support. She takes the baby to Titus' house but she is sent out by Titus' wife in presence of Titus. However, Titus feigns ignorance of the whole affair. This is captured thus:

The night she told Titus she was sure she was pregnant was the last time, day or night, that he turned up for their daily appointment. He had been lying in bed, stroking her shoulders. 'I am pregnant, Titus. That was all it took to get him out... (p.59)

'You.' She pointed a finger. 'You come into my house and accuse my husband of fathering your baby. How dare you? Eh? How. Dare. You?' Her voice was soft and the half-smile of before stayed on her lips so that Efe thought that perhaps it was no smile at all but something else. A sneer. Or something worse. 'Useless girl. Ashawo. May a thousand fleas invade your pubic hair. Useless goat. Shameless whore, Ashawo. Just take a look at yourself. Small girl like you, what were you doing with a man? At your age what were you doing spreading your legs for a man, eh? Which girl from a good home goes around sleeping with a man who is old enough to be her father, eh? Answer me, you useless idiot. I see you can't talk any more. You have gone dumb, abi? And you have the cheek to show your face. You were not afraid to come into my home with that thing in your hands, eh? You were not scared to ring my doorbell and show your face, eh? Now I am going to shut my eyes and before I open them I want both you and that bastard of yours out of my home' Even without looking at Titus, Efe knew that he was still eating. She could hear him smacking his lips as he sucked bone marrow. She got up and slowly walked out. (p.70-71)

These issues that are captured in the excerpt are social realities that are common in Lagos, Nigeria, the milieu of the novel. As Titus rejects Efe and his wife sents her out of his house, Efe leaves and swears to keep the baby and give it a good life. She works in three offices in a day cleaning to make money and take care of her son, siblings and herself. The demands get too much and when she meets Dele he promised to send her to Europe where she could work and earn big money for herself and takes good care of her son and family. This is how Efe fall victim of Dele's trafficking ring and ends up in Antwerp, Belgium, working as a prostitute to make money for Dele.

Ama is also one of the sex workers in Antwerp under Dele. She comes from Enugu in Nigeria. She fall victim of Dele's trafficking as a result of the frustration and abuses she faces as a child in the hands of her parents, her mother and stepfather. 
As a child, Ama is restrained from playing with other children and from talking to anybody outside of her home which is made up of only her mother and stepfather. Her stepfather rapes her the day she celebrates her eighth birthday. This continues without her mother intervening until she began her menstruation at the age of eleven. She graduates from secondary school and finds it difficult to gain admission into the university as she fails entry examinations. She is frustrated and then her stepfather comes home one day and began insulting her of being a failure. She feels bad and shouts at him that he is not her father that he rapes her for many years. The stepfather, Brother Cyril, becomes angry and sends her away from his house. This is presented thus:

...For Ama's big party her father, predictably, wore one of his white safari suits. After Ama had blown out the candles and the cake had been eaten and the clown had made the children laugh and the cameraman had captured all the joy and laughter on video, after the guests had gone and Ama had been sent to bed certain that this was the happiest day of her entire life, her father floated into her room in his white safari suit. In the dark and dressed all in white, Ama thought that he was a ghost and would have screamed if he had not pre-empted her by covering her mouth with one broad palm and smothering the scream in her throat. With the other hand he fumbled under her nightdress, a cotton lavender gown with a print of a huge grinning bear. (p.131-132)

This passage shows a nuanced and graphic description of a rape incidence of a minor by an adult which fits in the realist tradition. More, this act of crass abuse of Ama by her stepfather, Brother Cyril, violates her childhood, destroys her sense of belonging and makes her mentally deranged. She loses her sense of dignity and self-esteem. She then longs for admission in the university as an escape from her stepfather's brutality. But fortune does not smile at her until the stepfather mocks her and she shouts at him and is sent packing. She left for Lagos to stay with an aunt, Mama Eko. From there she is not satisfied with her life and then Dele steps in with an offer to get her to Europe and she falls for it.

Joyce, whose real name is Alek, is the last of the four girls and Sisi's friend portrayed in the novel. She is from Sudan and changes her name from Alek to Joyce to leave her ugly experiences in Sudan behind and live a fresh life. Her family members are killed in a militia attack by the janjaweed militia during the Sudanese civil war. She is raped by the militia, so many men taking turns to rape her. And at the end she is left half dead. She wakes up later and joins other survivals of the attack as they go to a United Nations (UN) refugee camp. In the camp Joyce meets a Nigerian peacekeeper, Polycarp, they fall in love and Polycarp returns to Lagos, Nigeria, with her. He intends to marry her but his mother would not allow him marry a foreigner especially being the first son. He thus takes Joyce to Dele to help her go abroad so that she can find something better to do and take care of herself. It is therefore through this way that Joyce too becomes Dele's sex worker in Antwerp, Belgium. (p.185- 189)

\section{Conclusion}

This paper attempts an evaluation of realism in Unigwe's On Black Sisters' Street (2010). It resolves that the novel dwells more on character than plot and also revolves on the common, the social and the contemporary issues in society which affirm its realist bearing. Also, the concerns of the novel, which are the socio-economic and psychological challenges of the lower class young women in Nigeria, have brought to the fore the social reality of life of the lower class in Nigeria and immigrants in Europe. From the tales of the four prime female characters, Sisi, Efe, Ama and Joyce, who are prostitutes in Antwerp, Belgium, it is clear that young Nigerian and African women are suffering from social injustice, unemployment, inequality and prejudice that have made them vulnerable. Therefore well placed individuals, parents, civil society organizations and the government should make efforts to improve and secure the lives of young women in order to help them escape from their vulnerabilities.

\section{References}

Becker, G. J. (1980). Realism in modern literature. New York: Frederick Ungar.

Coyle, M. \& Garside P. et al. (1987). (Eds). Encyclopedia of literature and criticism. Faber and Faber.

Cuddon, J. A. (1998). The penguin dictionary of literary terms and literary theory. (Rev) C. E. Preston. Fourth Edition. London: Penguin Books.

Defoe, D. (1719). Robinson Crusoe. London: William Taylor.

Eze, C. (2014) Feminism with a big "F": Ethics and the rebirth of African feminism in Chika Unigwe's On Black Sister's Street. Research in African Literatures, 45(4),pp.89-103.

Fielding, H. (1749). Tom Jones. London: Andrew Millar.

Gikwandi, S. (2007). African literature and the colonial factor. A. Quayson \& T. Olaniyan (Eds) African literature: An anthology of criticism and theory. Malden: Blackwell Publishers. pp51-62.

Habib, M A R. (2011). Literary criticism from Plato to the present an introduction. Malden: Willey-Blackwell.

Hasan, M. N. (2015). The eighteenth century and the rise of English novel". International Journal of Literature and Arts, 3(2), pp.18-21.

Hurwitz,N.SocialRealismLiterature,Theater\&Films.Study.com.Accessed, $1^{\text {st } M a r c h, 2021 R e t r i e v e d f i l e: / / / s t o r a g e / e m u l a t e d / 0 / P ~}$ HXBrowser/Offline\%20pages/social\%20Realism\%20Literature,\%20Theater\%20\&\%20Films\%20\%20Humanities\%2 0class $\% 20 \% 7 \mathrm{C} \% 20$ study.com.mht 
Ibeku, I. A. (2013). Sexuality and diasporic experiences in Chika Unigwe's On Black Sisters' Street. Department of English and Literary Studies, Federal University, Oye-Ekiti. pp.1-16

Irele, A. F. (2010). (Ed). The Cambridge companion to the African novel. Cambridge: Cambridge University Press.

Kamalu, I \& Ejezie B. O. (2014). Ideational representation of prostitution in Chika Unigwe's On Black Sisters' Street. Department of English Studies University of Port-Harcourt. pp.239-259.

Kearns, K. (1996). Nineteenth century literary realism: Through the looking glass. Cambridge University Press.

Literary Devices. Definition of Realism. Accessed, $15^{\text {th }}$ April, 2021. Retrieved-https://literarydevices.net/realism/

Orabueze, F. O. (2013). The law and slave trade: An evaluation of sex-slavery in Chika Unigwe's On Black Sisters' Street. Nsukka Journal of Humanities, 21, pp.47-72.

Rohmann, C. (1999). A world of ideas: A dictionary of important theories, concepts, beliefs, and thinkers. New York: Ballantine Books.

Snircova, S. (2015). Realism, modernism, postmodernism five modern literary texts in context. Kosice: Pavol Jozef Safarik University.

Umezurike, U. P. (2013). Sexuality and subjectivity in Chika Unigwe's On Black Sister's Street. Unizik Journal of Arts and Humanities. pp.1-25.

Unigwe, C. (2010). On Black Sister's Street. London: Vintage Books. 